\title{
Awareness and knowledge of phytonutrient food sources and health benefits for functional food application among health food store customers in the Cape Town city bowl
}

\author{
Marlè Braun and Irma Venter
}

\section{Opsomming}

Fitonutriënte speel ' $\mathrm{n}$ belangrike rol in die verwantskap tussen dieet en die voorkoming van chroniese degeneratiewe siektes. Dié wetenskaplike gegewens bied die voedselindustrie die geleentheid om funksionele voedsels te ontwikkel wat fitonutriënte beklemtoon. Verbruikers wat onbekend met fitonutriënte is, bemoeilik suksesvolle bemarking van sulke funksionele voedsels omdat dit ' $n$ verbruiker met kennis en begrip van dieet en gesondheid vereis. Die voedselindustrie behoort sulke voedselontwikkeling te weerhou totdat verbruikers voldoende kennis en begrip van fitonutriënte het vir oorgang van gewildheid na suksesvolle bemarking in die evolusie van verbruikersaanvaarding.

Omdat Suid-Afrika ' $\mathrm{n}$ ontluikende mark vir funksionele voedsels is, het die studie die volgende verken: 1) Bewustheid van die term "fitonutriënte" en spesifieke fitonutriënte soos beta-karoteen, isoflavone, fitoestrogene, likopeen, kwersitin, antosianiene, limonoïede en allielsulfiede; 2) Kennis van die voedselbron en die verwante gesondheidsvoordeel van spesifieke fitonutriënte; en 3) Of die bewustheid en kennis van die aanbevole daaglikse groente en vrugte inname porsies en hul werklike inname verband hou met die bewustheid van die term "fitonutriënte". Die opname is gedoen onder verbruikers wat twee gesondheidswinkels in die stadskom van Kaapstad besoek het. ' $n$ Onderliggende doel van die studie was om te bevestig of die deelnemers as gesondheidsbewuste verbruikers beskou kon word in die aanname gemaak dat dié groep persone moontlik bekend is met die onderwerp.

Die deelnemers moes ' $n$ voorafgetoetste self-geadministreerde vraelys voltooi. Een honderd en twaalf persone, $79,5 \%$ van die persone wat uitgenooi is, het deelgeneem.

Sowat ' $n$ derde van die deelnemers $(36,6 \%$ en $33 \%$ onderskeidelik) was bewus van die term "fitonutriënte" en die "5-'n-Dag" konsep. Meer deelnemers het die betekenis van die konsep $(21,4 \%)$ as fitonutriënte $(4,5 \%)$ korrek aangedui. Die deelnemers was die meeste bewus van die fitonutrient beta-karoteen $(88,4 \%)$, terwyl allielsulfiede die minste bekend was $(5,4 \%)$. Die deelnemers was meer bekend met die voedselbronne as die gesondheidsvoordele van fitonutriënte. Brokkoli is die voedsel wat deur die meeste van die deelnemers $(75,6 \%)$ aangedui is as " $n$ ryk fitonutrient bron. Meer deelnemers wat bewus is van die term "fitonutriënte", kon die daaglikse aantal aanbevole groente porsies korrek aandui $(58,5 \%)$, as diegene wat dit nie ken nie $(40,8 \%)$. Dit is nie ten opsigte van die aantal vrugte porsies gevind nie. Meer deelnemers wat die term "fitonutriënte" ken, eet die aanbevole daaglikse aantal porsies groente (22\%) en vrugte $(73,2 \%)$ as deelnemers wat onbewus van die term is $(9,9 \%$ en $60,6 \%$ onderskeidelik). Die meerderheid deelnemers wat die term "fitonutriënte" en die spesifieke fitonutriënte ken gebruik dieetsupplemente. Hulle kan dus as gesondheidsbewuste verbruikers beskou word.

Omdat die deelnemers wat gesondheidsbewus is, slegs beperkte kennis van sommige van die fitonutriënte en hul voedselbronne en gesondheidsvoordele getoon het, behoort die Suid-Afrikaanse voedselindustrie omsigtig te wees in die ontwikkeling van funksionele voedsels wat fitonutriënte beklemtoon. Die algemene publiek sal waarskynlik minder bewus en ingelig wees as die deelnemers aan die studie. Aansienlike blootstelling is gevolglik nodig om die belang van fitonutriënte in gesondheid en siekte voorkoming bekend te stel.

\section{- Ms Marlè Braun \\ - Mrs Irma Venter \\ Department of Agricultural and Food Sciences Cape Peninsula University of Technology}

\section{ACKNOWLEDGEMENTS}

The authors wish to acknowledge:

- The Cape Peninsula University of Technology for financial assistance

- Mr JC Lombard and Ms C Uys for their contribution to the statistical analysis of the data

- Prof E van Aswegen for the editing of the article. 


\section{INTRODUCTION}

Consumers began to view food from a different perspective since the early 1990s as the scientific evidence of the role between diet and disease evolved (Hasler, 2000). Consequently, healthier eating (health) became one of the top food trends among consumers (Sloan, 2007a) and the number one driver for product development throughout the global food industry (Sloan, 2007b). Scientific evidence of the role between diet and disease, together with an aging population, increased health-care costs, health consciousness, and changes in food regulations coalesced to create the beginning of a new era in the food industry, namely, functional foods (Hasler et al, 2004).

With no universally accepted definition, the American Dietetic Association in a position paper has defined functional foods as "any unmodified whole food or modified food that provides health benefits beyond basic nutrition". Unmodified whole foods, such as vegetables and fruit, represent the simplest form of functional foods (Hasler et al, 2004). One of the most compelling reasons for the widespread interest in functional foods comes from the generally consistent findings that increased vegetable and fruit consumption is accompanied by a reduced disease risk (Block et al, 1992; Steinmetz \& Potter, 1996). The natural presence of non-nutritive plant substances, known as phytonutrients (also commonly referred to as phytochemicals), provides vegetables and fruit with these beneficial health properties as they have the potential to modulate human metabolism favouring the prevention of cancer and other diseases (Ferrari \& Torres, 2003). For example, broccoli, carrots, and tomatoes are considered functional foods (unmodified) because they are respectively rich in sulforaphane, betacarotene and lycopene (Hasler et al, 2004), which are in turn three of the thousands of phytonutrients that have been identified in plant foods. These three phytonutrients are in particular known for their antioxidant and cancer preventative properties (Hasler, 2000). Modified functional foods can include foods that have been fortified with nutrients (vitamins, minerals) or enhanced with phytonutrients (beta-carotene, lycopene, anthocyanidins) or botanicals (Echinacea, Aloe Vera), providing them with potential health benefits (Hasler et al, 2004). Only phytonutrient functional foods will be addressed in this article.

Even though huge opportunities exist for the development of functional foods, various constraints affect or complicate successful commercialisation (Gray et al, 2003). According to Worthington and Zammer (2000:2) four consumer demands, namely taste, convenience, price and simple proposition must be met for the successful commercialisation of a functional food product. Meeting these demands is regarded as the golden rule in all food product development. A simple proposition, when referring to this study, is the consumer's general understanding of the link between a product's phytonutrients and its health benefit(s). It is necessary for the phytonutrient and its health benefit to reach a significant level of interest and understanding among mainstream consumers before they are ready for product development action (Sloan,
1998). Hence, if consumers are uninformed about the potential health benefits of functional foods or their phytonutrient rich ingredients, few will purchase and benefit from these foods, and the food industry will have little incentive to further such product development (Institute of Food Technologists, 2005:46). According to an industry survey, $83 \%$ of new food products introduced into the retail sector fail (Asp, 1999). Two of the reasons identified that specifically contribute to the failure of functional foods are 1) the uninformed consumer and 2) the fact that functional foods challenge the knowledge and understanding of consumers about nutrition and its health implications (Mollet \& Rowland, 2002). If a health benefit of a product is clearly understandable or perceptible, such as weight loss or stress reduction, then the product is much more likely to succeed (Worthington \& Zammer, 2000:2). The challenging aspect for the consumer to understand phytonutrient functional foods is centred in the required knowledge of the active phytonutrient, its major food source(s) and its link with health. For consumers to understand any of these three components, persistent promotion of nutritional information is necessary, otherwise the phytonutrient will never gain consumer awareness and knowledge and the food industry will have little incentive to further such product development (Institute of Food Technologists, 2005:46). Aggressive promotion of the health benefits of phytonutrients has been the successful formula for the dietary supplement industry over the years (Witwer, 1999).

The markets for and product ranges of functional foods mainly reside in First World countries such as the United States (US), Europe and Japan (Mollet \& Rowland, 2002). Locally in South Africa (SA), the functional foods market is only emerging, especially for phytonutrient-emphasised functional foods. South Africans tend to be health conscious and various dietary supplements are bought monthly to prevent disease, but many other food product initiatives (functional foods), other than those allergy related, become product failures shortly after market release (McGuire, 2004). However, the topic of phytonutrients seems to feature prominently in gatherings of the South African Association of Food Science and Technology. The subject of phytonutrients was, for example, the major discussion topic of the "Ingredients" symposium in Bellville, Western Cape, on 10 March 2004. The fundamental question therefore is, whether this food product initiative will work in South Africa? In other words, is the South African food industry in such a position to initiate development or marketing of functional foods (whether modified or unmodified), emphasising phytonutrient ingredients without having them fail because of an uninformed consumer? However, to answer this question, answers to other questions must first be sought, which are the focus of this study, namely are South African consumers aware of phytonutrients and has the South African consumer gained adequate knowledge of phytonutrients to be able to understand such functional foods?

In view of the fact that $\mathrm{SA}$ is an emerging market for functional foods, it was assumed that the general consumer would be unaware of phytonutrients. Owing to 
the latter assumption, this study investigated 1) phytonutrients naturally present in unmodified whole foods such as vegetables and fruit and 2) a sample that most likely would be aware of the topic, namely health -conscious consumers, who were recruited at health food stores in the greater Cape Town City Bowl area. The objectives of this study were to ascertain 1) the awareness of the term "phytonutrients" and specific phytonutrients; 2) basic knowledge of their food sources and most associated health benefits; and 3) whether the awareness and knowledge of vegetable and fruit intake recommendations and their actual consumption were associated with awareness of the term "phytonutrient". A subsidiary objective of the study was to confirm that the participating sample could be regarded as health-conscious consumers. The information obtained from health food store customers could 1) provide insight into the awareness and basic knowledge of the general public regarding phytonutrients, 2) provide the food industry with information to assist in the development of successful phytonutrient-emphasised functional food products and 3 ) provide direction for developing communication strategies and messages to assist in promoting phytonutrient awareness among South Africans. No information is currently available on consumer awareness and knowledge of phytonutrients in SA.

\section{METHOD}

\section{Phases investigated in the consumer acceptance} evolution

Sloan (1998) and Witwer (1999) both refer to a threephase model in which food ingredients or markets trends are tracked for consumer acceptance (Figure 1). Food product development should not start until the emerging trend (in this study phytonutrients) has gained enough interest and understanding to reach the popularisation/growth and commercialisation/ mature phases (Sloan, 1998). During the emerging phase the majority of mainstream consumers are just becoming aware of the health benefits of specific food ingredients (or phytonutrients) (Witwer, 1999), as they enter the "radar screen". When consumer awareness has increased to where they may or may not understand the health benefits (of phytonutrients), the trend is entering the popularisation phase. At this phase consumers should already have knowledge, but might still not have an understanding of the ingredient or trend. Only during the second part of the popularisation phase, when consumers indicate understanding, should marketers be readying new products for massmarket entry (Sloan Trends Inc., 2007:1). During the commercialisation phase, consumers generally understand the health benefits (of phytonutrients) without additional information (Witwer, 1999). Manufacturers should already be in the marketplace in this phase. Because the evolution of consumer acceptance of an ingredient or trend depends on the consumer's awareness (emerging phase), knowledge (popularisation phase) and understanding (commercialisation phase), these three domains need to be investigated. In this study the focus primarily is, as previously indicated, on consumer awareness of phytonutrients and specific phytonutrients and consumers' basic knowledge of its unmodified food source and most associated health benefit, as a measure to determine if the South African market is ready for food product development and marketing of phytonutrient functional foods.

\section{Key concepts investigated in the developed ques-} tionnaire

A self-administered questionnaire was developed to obtain the following information:

Dietary supplement use The participants were requested to indicate whether they used any dietary supplements. Dietary supplements include any vitamins, minerals, amino acids, botanicals, and/or plant

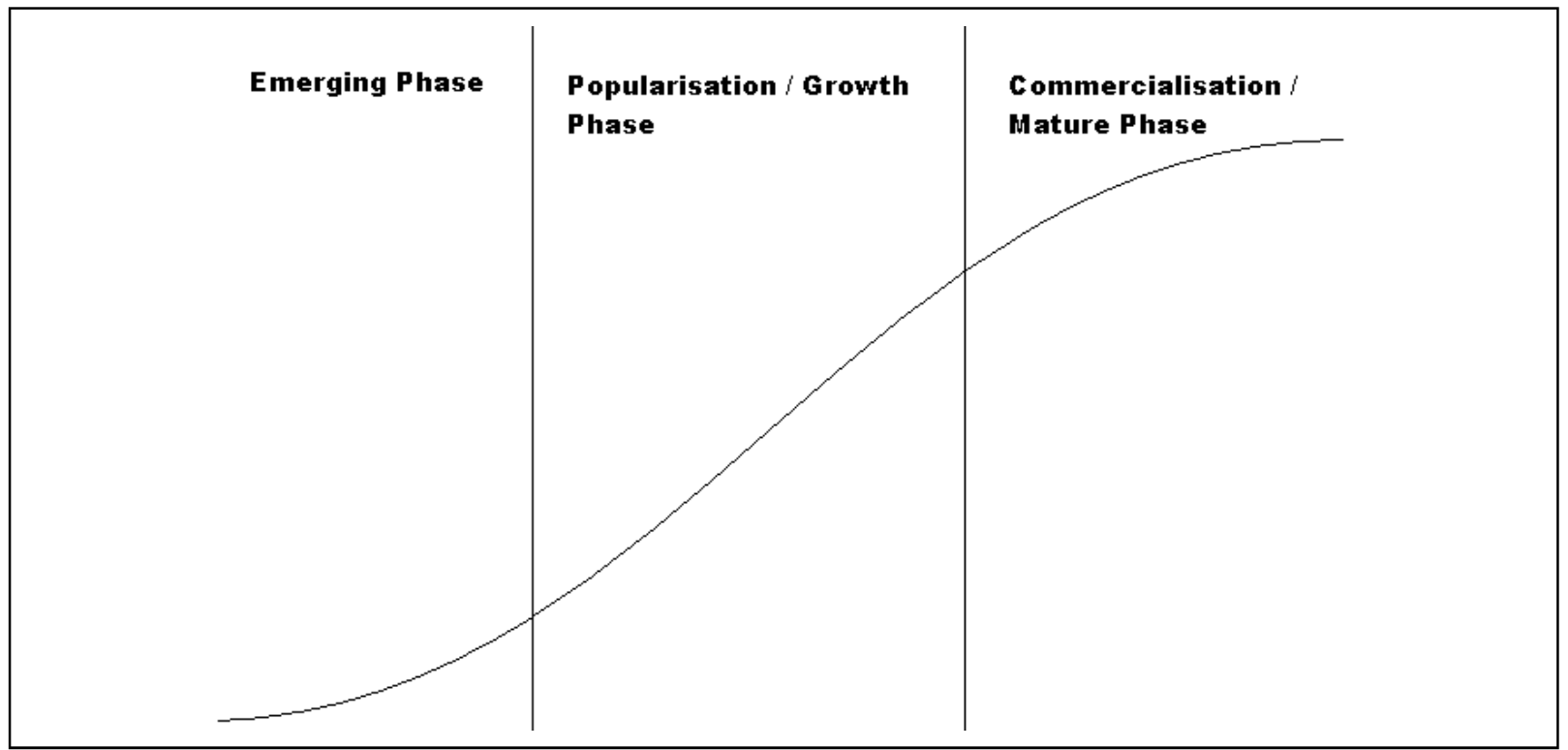

FIGURE 1: $\quad$ EVOLUTION OF CONSUMER ACCEPTANCE (Adapted from Sloan, 1998 and Witwer, 1999) 
substances (Dietary Supplement Health and Education Act of 1994:103-417). The information regarding dietary supplement use was required to determine whether the research subjects, who were health food store customers, were indeed health conscious. It has been suggested that supplement users are health conscious. Slesinski and co-workers (1996) found that a large number of the persons who practised healthier lifestyle characteristics were supplement users.

Phytonutrient awareness and food source, and associated disease knowledge Awareness was determined by asking the participants, "Have you heard about...?" Awareness of the term "phytonutrients" and specific phytonutrients such as beta-carotene, isoflavones, phytoestrogens, lycopene, quercetin, anthocyanidins, limonoids and allyl sulphides was determined. The phytonutrients investigated were the subject of many articles and advertorials in popular South African magazines and newspapers during 2004, when the study was planned. In addition to the publicised phytonutrients, the study also included those phytonutrients present in the top of mind vegetables and fruit, which consumers perceive as healthy (National Institute of Nutrition, 2000:6; International Food Information Council, 2002:1). Participants aware of the term "phytonutrients" were also asked to provide their understanding of phytonutrients, that is, "naturally occurring substances in foods such as fruits, vegetables and cereal grains" (Wrick et al, 1993). These same participants (phytonutrient aware) were asked to identify for 12 food sources whether they were a rich or poor source of or did not have phytonutrients. Two nonphytonutrient food sources, namely fish and milk, were included with the listed sources.

Given that knowledge is necessary to understand phytonutrient functional foods, several basic knowledge questions regarding the richest food source for betacarotene, lycopene, allyl sulphides, phytoestrogens and anthocyanidins, and the disease linked/associated with lycopene, phytoestrogens, and anthocyanidins, were also included. Only the food source and the disease were determined as these are the two major knowledge aspects to understand functional foods, namely diet and health.

\begin{abstract}
Awareness and knowledge of vegetable and fruit intake recommendations and actual consumption Since the interest in phytonutrients evolved from the scientific evidence that an increased vegetable and fruit consumption could reduce the risk of developing disease (Block et al, 1992; Steinmetz \& Potter, 1996) and that those consumers who are aware of phytonutrients consumed more phytonutrients (Miller, 2002), questions regarding vegetable and fruit intake recommendation awareness, knowledge and actual consumption were also included in the questionnaire.
\end{abstract}

Awareness and knowledge of vegetable and fruit intake recommendations were determined by asking questions regarding the "5-A-Day for Better Health" concept, and the recommended vegetable and fruit intake servings to be consumed each day. A total of five servings of vegetables and fruit is recommended for consumption each day for good health. The five portions to be consumed each day are derived from the minimum number of vegetable (three - five) and fruit (two - four) servings. Questions regarding these three aspects were previously used successfully to determine awareness/knowledge of the recommendations regarding vegetable and fruit intake (Beech et al, 1999; Stables et al, 2002).

The understanding of the "5-A-Day for Better Health" concept, that is, "eating five vegetables and fruits each day" (Beech et al, 1999) was also determined. The "5A-Day" campaign was launched on the $19^{\text {th }}$ and $20^{\text {th }}$ of September 1995 in SA. This generic fresh produce campaign is aimed at consumers, encouraging them, through promotion and education, to eat at least five servings of vegetables and fruit a day to contribute to a healthier South African nation (About 5-A-Day, 2000:1).

Vegetable and fruit consumption was determined by providing vegetable and fruit serving descriptions to the participants for guidance (Sizer \& Whitney, 2003:36). This section regarding vegetable and fruit intake recommendation awareness, knowledge and actual consumption, was included to determine whether there was an association with the participants' awareness of the term "phytonutrients". Participants were also asked to list all the nutrients and nonnutrient substances, other than water, starch and sugars, present in vegetables and fruit that they were aware of.

Demographic information The information sought included details on gender, age, education, language use and ethnicity.

Clear instructions were provided for completion of the questionnaire. The questionnaire predominantly consisted of multiple-choice questions, except where the participants had to provide their understanding of the "5-A-Day for Better Health" concept and of the term "phytonutrient", in which case a short-answer question was used. The use of "none of the above" and "all of the above" responses was not included, as these almost always render the item less effective than it would be without them (Gronlund, 1993:57); however, the "don't know or unsure" response was used to eliminate guessing. The drafted questions and the answers provided were evaluated by a dietician and a tertiary institution lecturer in nutrition for content validity (Gronlund, 1993:175). Prior to the administration of the survey, a pre-test of the final questionnaire was conducted. This allowed the investigators to examine and reduce potential problems in the survey administration and to ensure face validity (Thorndike et al, 1991:126). Only a slight adjustment to the technical layout of the questionnaire was required by changing contingency questions to a box format (Babbie, 1992:154).

\section{Procedure and sample}

Two of the three health food stores located in the Cape Town City Bowl participated in the survey. An assumption was made that health food store custom- 
ers in the Cape Town City Bowl would represent a group likely to be aware of phytonutrients, and as such could serve as an upper limit for the awareness of phytonutrients among the general health-conscious population of the greater Cape Town area. The participant sample was systematically obtained by inviting every third customer to voluntarily participate by anonymously completing the self-administered questionnaire. Participants were recruited during the morning and afternoon hours on all days of the week. The study was conducted over 28 days in 2004.

\section{Data analysis}

The data were entered onto Microsoft ${ }^{\circledR}$ Excel 2000 (9.0.2720) spreadsheets and imported into SYSTAT® Software for analysis. The chi-square test was used to establish whether there was an association between data categories. Associations were considered significant if $p$-values were less than 0,05 .

\section{RESULTS AND DISCUSSION}

\section{Response rate}

One-hundred-and-forty-six health food store customers were invited to voluntarily participate in the study, of whom 116 completed the questionnaire at both the two health food stores. The response rate among those who agreed to participate was $79,5 \%$. Four questionnaires were rejected, as they were incomplete, providing for a final participant sample of 112 .

\section{Participant sample demographic characteristics}

The demographic characteristics of the participant sample were predominantly white, female, having a

\section{TABLE 1: DEMOGRAPHIC CHARACTERIS-} TICS OF PARTICIPANT SAMPLE

\begin{tabular}{|l|l|}
\hline $\begin{array}{l}\text { Demographic } \\
\text { characteristics }\end{array}$ & $\begin{array}{l}\text { Participant } \\
\text { sample }(n=112)\end{array}$ \\
\hline Ethnicity & \\
White & $84,8 \%(n=95)$ \\
Coloured & $5,4 \%(n=6)$ \\
Black & $0 \%(n=0)$ \\
Indian & $7,1 \%(n=8)$ \\
Other (Residential immigrants) & $2,7 \%(n=3)$ \\
\hline Gender & $75,9 \%(n=85)$ \\
Female & $24,1 \%(n=27)$ \\
Male & \\
\hline Highest educational level & $2,7 \%(n=3)$ \\
Primary & $17,0 \%(n=19)$ \\
Secondary & $80,4 \%(n=90)$ \\
Tertiary & \\
\hline First language & $21,4 \%(n=24)$ \\
Afrikaans & $69,6 \%(n=78)$ \\
English & $8,9 \%(n=10)$ \\
Other (French and German) & \\
\hline Age & $53,6 \%(n=60)$ \\
20-39 years & $42,9 \%(n=48)$ \\
$40-65$ years & $3,6 \%(n=4)$ \\
\hline 65 years and older & \\
\hline
\end{tabular}

higher education, English-speaking and mostly between 20 and 39 years of age (Table 1). Most of the participant sample was dietary supplement users $(81,3 \%)$. These results correspond with those of previous studies conducted on dietary supplement users which indicated that the demographic characteristics of supplement users were mainly female (Levy \& Schucker, 1987; Slesinski et al, 1996; Lyle et al, 1998), white (Levy \& Schucker, 1987; Slesinski et al, 1996), with a higher education history (Slesinski et al, 1996; Lyle et al, 1998) and of a younger age group (20 -39 years) (Levy \& Schucker, 1987). Furthermore, studies confirmed that supplement users are more health conscious (Block et al, 1994; Kirk et al, 1999) than non-supplement users. Thus the 91 health food store customers using dietary supplements $(81,3 \%)$ could possibly be assumed to be more health conscious than the non-supplement users visiting these stores. It was further found that a significantly higher percentage $(P<0,05)$ of the participants aware of the term "phytonutrients" were in fact supplement users $(95,1 \%)$ compared with those unaware of the term $(73,2 \%)$. This accentuates the association between supplement users being health conscious and having higher phytonutrient awareness. A Canadian study found that health food shoppers and supplement users were leading the way in their awareness of functional foods (National Institute of Nutrition, 2000:7). The majority of the participant sample aware of any of the specific phytonutrients investigated was also supplement users (Table 2$)(P>0,05)$.

\section{Awareness and knowledge of the food source and disease associated with specific phytonutrients, the term "phytonutrients" and the "5-A-Day" con- cept}

Beta-carotene was by far the most familiar phytonutrient (Table 3) to the health food store customers. Ninety-six percent of the beta-carotene-aware participants indicated that carrots were a rich source. The value of carrots to human health and as a major source of phytonutrients became widely known during the decades following World War II (Goldman, 2003). The recognition of beta-carotene as a phytonutrient and carrots as a food source thereof could be due to this being well documented. It could be assumed that beta-carotene is in the growth phase in the evolution of consumer acceptance. This should, however, be confirmed as no investigation was undertaken to determine whether the participants knew the health benefits associated with beta-carotene such as prevention of macular degeneration, cancer, etc. (Sizer \& Whitney, 2003:260-261). Table 3 indicates the awareness of phytonutrients in this study and a US study. The level of awareness of beta-carotene was equal for both studies.

The health food store customers in this study were just becoming aware of the term "phytonutrients" (Table 3 ). Although more participants were aware of the term "phytonutrients", only a few knew what the term meant $(12,1 \%)$, which indicates that the health food store customers do not know what phytonutrients are. It was surprising to find that the participants were equally aware of the " 5 -A-Day" concept 
TABLE 2:

AWARENESS OF SPECIFIC PHYTONUTRIENTS BY SUPPLEMENT USERS AND NONUSERS IN THE PARTICIPANT SAMPLE

\begin{tabular}{|l|c|c|}
\hline $\begin{array}{l}\text { Specific phytonutrient } \\
\text { awareness }\end{array}$ & Supplement user & Non-supplement user \\
\cline { 2 - 3 } & $\%(\mathbf{N})$ & $\%(\mathbf{N})$ \\
\hline Beta-carotene $(\mathrm{N}=99)$ & $82,2(82)$ & $17,2(17)$ \\
\hline Isoflavones $(\mathrm{N}=64)$ & $79,7(51)$ & $20,3(13)$ \\
\hline Phytoestrogens $(\mathrm{N}=76)$ & $76,3(58)$ & $23,7(18)$ \\
\hline Lycopene $(\mathrm{N}=25)$ & $92,0(23)$ & $8,0(2)$ \\
\hline Quercetin $(\mathrm{N}=12)$ & $91,7(11)$ & $8,3(1)$ \\
\hline Anthocyanidins $(\mathrm{N}=10)$ & $100(10)$ & $0(0)$ \\
\hline Limonoids $(\mathrm{N}=8)$ & $75,0(6)$ & $25,0(2)$ \\
\hline Allyl sulphides $(\mathrm{N}=6)$ & $100(6)$ & $0(0)$ \\
\hline
\end{tabular}

Results are only indicated for those aware of the specific phytonutrients

TABLE 3: $\quad$ AWARENESS OF SPECIFIC PHYTONUTRIENTS AND OF THE TERM "PHYTONUTRIENTS" AND THE "5-A-DAY" CONCEPT IN THIS SOUTH AFRICAN AND AN UNITED STATES STUDY

\begin{tabular}{|c|c|c|}
\hline Awareness & $\begin{array}{c}\text { This study } \\
2004 \\
(n=112) \\
\end{array}$ & $\begin{array}{c}\text { US study } \\
2002^{*} \\
(n=375)\end{array}$ \\
\hline & $\%$ of $\mathbf{N}^{\star *}$ & $\%$ of $\mathbf{N}$ \\
\hline Beta-carotene & 88,4 & 88,3 \\
\hline Isoflavones & 42,9 & 67,2 \\
\hline Phytonutrients & 36,6 & 43,2 \\
\hline "5-A-Day" concept & 33,0 & $60,6^{\star \star \star}$ \\
\hline Phytoestrogens & 32,1 & 30,9 \\
\hline Lycopene & 22,3 & 29,6 \\
\hline Quercetin & 10,7 & $\star \star * \star *$ \\
\hline Anthocyanidins & 8,9 & 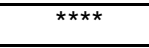 \\
\hline Limonoids & 7,1 & 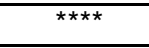 \\
\hline Allyl sulphides & 5,4 & $* * * *$ \\
\hline
\end{tabular}

TABLE 4: ASSOCIATION BETWEEN PARTICIPANT SAMPLE ( $\mathrm{N}=112)$ AWARENESS OF THE "5-ADAY" CONCEPT AND THE TERM "PHYTONUTRIENTS"

\begin{tabular}{|l|c|c|c|c|c|c|}
\hline \multirow{2}{*}{ "5-A-Day" concept* } & \multicolumn{4}{|c|}{ Term "phytonutrients"* } & \multicolumn{3}{c|}{ Total } \\
\cline { 2 - 8 } & \multicolumn{2}{|c|}{ Aware } & \multicolumn{2}{|c|}{ Unaware } & N & \% \\
\cline { 2 - 8 } & $\mathbf{N}$ & 17,2 & 24 & 21,4 & 41 & 36,6 \\
\hline Aware & 17 & 17,9 & 51 & 45,5 & 71 & 63,4 \\
\hline Unaware & 20 & 33,0 & 75 & 67,0 & 112 & 100 \\
\hline
\end{tabular}

${ }^{*}$ No association $(\mathrm{P}>0,05)$

(33\%) and the term "phytonutrients" (36,6\%), but not surprising that more participants understood the concept correctly $(21,4 \%)$ than they did the term "phytonutrients" $(4,5 \%)(n=112, P>0,05)$. The participants in this study were not necessarily aware of the " 5 - $A$ Day" concept if they were aware of phytonutrients, and vice versa $(P>0,05)$ (Table 4$)$. In the US, subscribers to a health/prevention magazine's awareness of the "5-A-Day" concept is almost double (60,6\%) (Miller, 2002) that of the health food store customer sample in this study (Table 4).

Phytoestrogens, a group of naturally occurring plant compounds such as isoflavones, coumestans and lignans, which exhibit estrogenic properties, are found mostly in soy (Kurzer \& Xu, 1997). Isoflavones and 
TABLE 5:

PERCENTAGE OF PARTICIPANTS AWARE OF THE SOURCES OF PHYTONUTRIENTS $(\mathrm{N}=41)$

\begin{tabular}{|l|c|c|c|c|}
\hline \multirow{2}{*}{ Sources } & Rich source & Poor source & No source & $\begin{array}{c}\text { Don't know or } \\
\text { unsure }\end{array}$ \\
\cline { 2 - 5 } & $\%$ & $\%$ & $\%$ & 24,4 \\
\hline Broccoli & 75,6 & 0 & 0 & 29,3 \\
\hline Oranges & 63,4 & 7,3 & 0 & 31,7 \\
\hline Garlic & 61,0 & 4,9 & 2,4 & 39,0 \\
\hline Guavas & 58,5 & 2,4 & 7,3 & 34,0 \\
\hline Soy & 56,1 & 2,4 & 7,0 & 31,7 \\
\hline Whole grains & 48,8 & 12,2 & 7,3 & 41,2 \\
\hline Rosemary & 41,2 & 9,8 & 12,2 & 39,0 \\
\hline Paprika & 31,7 & 17,7 & 34,1 & 31,7 \\
\hline Tea & 17,1 & 17,1 & 48,8 & 26,8 \\
\hline Coffee & 9,8 & 14,6 & 20,0 & 37,0 \\
\hline Milk & 22,0 & 22,0 & 14,6 & 34,1 \\
\hline Fish & 43,9 & 7,0 & & \\
\hline
\end{tabular}

phytoestrogens were the second and third most "familiar" phytonutrients (specific) to the participating sample (Table 3). Most of the participants aware of phytoestrogens $(88,9 \%)$ indicated that soy beans were a rich source. A large majority of them $(72,2 \%)$ also indicated that phytoestrogens reduced the risk of breast cancer. Approximately $68 \%$ of these participants $(67,7 \%)$ were able to provide the food source and the disease relation associated with phytoestrogens $(P>0,05)$. Only $2 \%$ of the Canadian consumers associated the benefits of soy with breast cancer (National Institute of Nutrition, 2000:21). Levels of awareness increase with time (International Food Information Council, 2002:2) and it could be assumed that the awareness of the Canadian consumers would have increased from the year 2000 to 2004. It is unclear what contributes to the participants in this study's awareness regarding phytoestrogens, their food source and disease relation. In SA, over $60 \%$ of the people who drink soy milk do so for health reasons. It is, however, not known for which health reasons South Africans consume soy milk. Although lactose intolerance is common in SA, it mainly occurs in the black population, who most likely cannot afford this product (Neall, 2005).

The awareness of lycopene was disappointingly low $(22,3 \%)$, as it had been the topic of several articles and advertorials in South African magazines, which are a major source of nutritional information to South Africans (Charlton et al, 2004). Most of the participants $(68 \%)$ who were aware of lycopene in this study indicated tomatoes as a rich food source, but not as many were able to associate it with prostate cancer $(44 \%)$. Since the sample comprised mainly females, it could be assumed that females are not that knowledgeable about the association between lycopene and prostate cancer. Fewer than half of the participants aware of lycopene $(40 \%)$ were able to provide the food source as well as the disease risk relation associated with it $(P>0,05)$. It appears that more participants knew the food sources of phytonutrients than the disease relationship as was found with both phytoestrogens and lycopene.

It was also found that participants were likely to be more familiar with phytonutrients that are closely associated such as isoflavones and phytoestrogens, and beta-carotene and lycopene. All the participants $(22,3 \%)$ aware of lycopene were also aware of betacarotene $(P<0,05)$ and fewer than a third of the participant sample $(27,7 \%)$ were aware of both isoflavones and phytoestrogens $(P<0,001)$. The reason for this finding should, however, be further investigated. The overwhelming majority of the participants were generally unaware of the remaining phytonutrients (quercetin, limonoids, anthocyanidins and allyl sulphides) (Table 3).

Those participants aware of the term "phytonutrients" ( $n=41)$ were also asked to indicate for each of the twelve foodstuffs indicated in Table 5 , whether it was a rich or poor source of, or did not contain, phytonutrients. Broccoli was the foodstuff indicated by most $(75,6 \%)$ to be a rich source of phytonutrients. The awareness of vegetables (specifically broccoli) as a source of phytonutrients along with fruit (i.e. guavas and oranges) and garlic was higher than that for soy, whole grains, herbs and spices (i.e. rosemary and paprika). The lowest awareness was found for tea and coffee. Broccoli is one of the "top of mind" foods that consumers believe to have health-enhancing qualities (National Institute of Nutrition, 2000:6; International Food Information Council, 2002:1). In a Canadian consumer survey, $14 \%$ of the consumers named broccoli as a food that provides health benefits - most frequently, a reduced risk of cancer (National Institute of Nutrition, 2000:19). The immense awareness of broccoli as a rich source of phytonutrients in this study could be due to consumers' awareness of broccoli as a food with health-enhancing properties. The awareness of coffee as a source of phytonutrients was es- 
pecially low. It could be assumed that the reason for the low awareness of coffee as a phytonutrient source was due to the negative association around caffeine. Ferrari and Torres (2003) indicated that coffee, tea, citrus fruits, garlic, cruciferous vegetables (broccoli), rice (wholegrain), tomato and soy products, which are all rich sources of phytonutrients, are functional foods that should be consumed more widely in the world. A misconception seemed to exist regarding fish and milk as sources of phytonutrients. Fish and milk are publicised for their health properties as they respectively contain the fatty acids omega-3 and conjugated linoleic acid (CLA) (Hasler, 1998). These two fatty acids are not phytonutrients and therefore were not investigated in this study, but were included in the food listing to identify whether participants would incorrectly indicate animal foods/fish as phytonutrient sources (Table 5).

\section{Association between phytonutrient awareness and the recommended vegetable and fruit intake serv- ings and actual vegetable and fruit consumption}

More participants aware of the term "phytonutrients" knew the recommended daily vegetable intake servings to be consumed (three - five and more servings) $(58,5 \%)$ than those participants who were unaware of the term "phytonutrients" $(40,8 \%)(P>0,05)$. This was, however, not found for the recommended fruit intake servings per day as an equal number of participants who were aware of the term "phytonutrients" $(92,7 \%)$ and those unaware $(91,5 \%)$ were cognisant of the recommended daily fruit intake servings to be consumed (two - four and more servings) $(P>0,05)$. $A$ US study found that phytonutrient knowledge motivates some people to consume more fruits, vegetables and whole grains (Miller, 2002). More participants aware of phytonutrients consumed the recommended three - five and more servings of vegetables (22\%) and two - four and more servings of fruit $(73,2 \%)$ per day than those participants who were unaware of phytonutrients $(9,9 \%$ and $60,6 \%$, respectively) $(P>0,05)$.

When the participants were asked what the composition (nutrients and non-nutrients) of vegetables and fruit is, $41,1 \%$ of the participants could not mention any nutrient and non-nutrient substance present in vegetables and fruit although $45,5 \%$ listed vitamins and $39,3 \%$ listed minerals as components found in vegetables and fruit. Of the remaining participants only $3,6 \%$ of the participants indicated that phytonutrients were present in vegetables and fruit (these participants included those who indicated awareness of such phytonutrients as flavonoids and carotenoids). This clearly indicates that the participants' knowledge is limited, as they are not able to list the components present in vegetables and fruit.

\section{CONCLUSIONS}

The "5-A-Day" concept had previously been indicated in the US to be in the growth phase of the evolution of consumer acceptance (Witwer, 1999), while phytonutrients were considered an emerging trend (Sloan,
1998). This is currently also evident for the health food store customer market in the Cape Town City Bowl, as an equal number of participants were aware of the concept and phytonutrients, but more participants knew the meaning of the "5-A-Day" concept than the term "phytonutrients".

The high awareness of beta-carotene among the health food store customers could place betacarotene, as phytonutrient, in the growth phase of the evolution of consumer acceptance. Nevertheless these customers are just becoming aware of most of the other (specific) phytonutrients investigated (emerging phase). The only other exception is phytoestrogens, which because of the dominance of female participants in this sample, could be emerging to the growth phase among females in this market.

The overall level of phytonutrient awareness and knowledge found for this study was limited and indicates that certain and possibly more phytonutrients are in the emerging phase and not in the growth phase of consumer acceptance in this market. However, from the aspects investigated it can be concluded that phytonutrients are not yet ready to be associated with functional foods in SA except for betacarotene and possibly phytoestrogens in foods targeted at the female as mainstream market. The participants were more knowledgeable about the specific phytonutrient food sources than their health benefit, which indicates that the participants have not yet gained adequate understanding. Furthermore, the participants were also not knowledgeable regarding the level of phytonutrients in listed unmodified food sources. Therefore the food industry will need considerable research identifying not only the target markets but also which foods to utilise as either unmodified or modified phytonutrient functional foods. Consideration should be given to the use of foods such as vegetables (especially broccoli), fruit and garlic above soy, whole grains, herbs and spices, and caution should be exercised particularly in using coffee. Furthermore, extensive marketing campaigns will be necessary so that consumers can understand the product health attributes and as a result be motivated to purchase the products, as more participants in this study knew the food source of specific phytonutrients than their disease relationship.

Some educated and proactive consumers, such as health food store customers, would have knowledge about the food sources and health benefits of phytonutrients and as such functional foods, but the general population might not have any or very limited knowledge of these non-nutrients and foods. It could therefore be assumed that health food store customers and/or supplement users would also be leading the way in the awareness of phytonutrients in SA as was found in a Canadian study of functional foods (National Institute of Nutrition, 2000:7).

\section{RECOMMENDATIONS AND RESEARCH LIMITATIONS}


Generalisation of the results could be limited because this study focused only on information concerning specific phytonutrients, their food sources and health benefits obtained from health food store customers in the Cape Town City Bowl. Statistical inference about the health food store customers in the Cape Town City Bowl only can therefore be made. A survey covering the general public is recommended in this regard.

Typical qualitative focus-group approaches to gathering consumer information are partially responsible for the nine out of ten new food products that fail in the marketplace every year. A more quantitative approach to understanding consumer needs can up the odds of a product's success (Worthington \& Zammer, 2000:3). This study can be seen as a more quantitative approach and South African food developers involved in or considering phytonutrient functional food development and marketing can use the data gathered as an initial source of information as basis for their decisionmaking.

When the food industry plans to develop new functional food products to improve public health, it is important to determine the awareness of the target consumer group and whether they will accept the ingredient and understand its health benefits. When determining consumer awareness and knowledge of phytonutrients it is necessary to investigate both the food source and the health benefits. Both these aspects (diet and health) of functional foods are necessary to determine consumer understanding of the topic. This will provide evidence as to where the phytonutrient trend lies on the evolution of consumer acceptance. A limitation of this study was the lack of investigation into participant knowledge of the health benefits of beta-carotene.

If consumers do not understand the health benefit, it indicates that investment in the form of a consumer education programme is required to publicise the benefits. Considerable educational effort and repetition of nutritional messages are necessary for the general public to recognise the diet - health relationship. Awareness depends more on the length of time consumers have been hearing about an association than it does on the degree of concern for the health condition (International Food Information Council, 2002:2). Broader and continued communication should therefore lead to better nutritional awareness and understanding that will benefit consumer health (Mollet \& Rowland, 2002).

As the knowledge develops, it must be communicated fully, clearly, and in a timely manner to consumers. Food industry personnel, health professionals, educators, government officials, and the media can provide this information to consumers. Several guidelines to increase phytonutrient awareness among South African consumers through communication are indicated:

- Communicate with accuracy. To reduce the various misconceptions relating to aspects of food, nutrition and health, educators have to become more actively involved with the training of health and food industry professionals and the nutritional health media.

- Clearly convey the differences between emerging and consensus science. Tell consumers where new findings fall on the research continuum and within the overall body of evidence.

- Build on consumers' desire to know the benefits associated with eating certain foods. In food labelling, consumers prefer a health claim to a content claim (National Institute of Nutrition, 2000). However, health claims can only be made when supported by scientific evidence (Hasler et al, 2004; Institute of Food Technologists, 2005:35).

- Adopt a single term to facilitate communication, i.e., phytonutrients. Terms also used to describe these compounds include "phytochemicals" and "plant chemicals", which could lead to confusion among consumers.

- Increase awareness of phytonutrients by using health messages such as the " $5-A-D a y "$ concept. The resulting increased awareness of the concept and phytonutrients among South African consumers could possibly result in increased actual vegetable and fruit intake as was evidenced in this participant sample and a US study (Miller, 2002). This would be a worthy effort as the intake of vegetables and fruit is low among South Africans (Langenhoven et al, 1995). The limited awareness of the composition of vegetables and fruit found in this study could also possibly be addressed through such communication.

\section{REFERENCES}

ABOUT-5-A-DAY. 2000. Take the 5-A-Day Challenge. Available online. URL: http://www.5-a-day.co.za/. Accessed 11 October 2005.

ASP, EH. 1999. Factors affecting food decisions made by individual consumers. Food Policy 24:287294.

BABBIE, E. 1992. Conceptualisation and instrument design. In Babbie E. Survey research methods. Belmont, California. Wadsworth.

BEECH, BM, RICE, R, MYERS, L, JOHNSON, C \& NICKLAS, TA. 1999. Knowledge, attitudes, and practices related to fruit and vegetable consumption of high school students. Journal of Adolescent Health 24:244-250.

BLOCK, G, PATTERSON, B \& SUBAR, A. 1992. Fruit, vegetables, and cancer prevention: a review of the epidemiological evidence. Nutrition Cancer 18:120.

BLOCK, G, SINHA, R \& GRIDLEY, G. 1994. Collection of dietary-supplement data and implications for analysis. American Journal of Clinical Nutrition 59 (suppl):232S-239S.

CHARLTON, KE, BREWIT, P \& BOURNE, LT. 2004. Sources of nutrition information among black urban South African woman, with a focus on messages related to obesity. Public Health Nutrition 7:801-811.

DIETARY SUPPLEMENT HEALTH AND EDUCATION ACT OF 1994. 108 Stat. 4325. Public Law, United States Congress.

FERRARI, CKB \& TORRES, EAFS. 2003. Biochemical pharmacology of functional foods and prevention 
of chronic diseases of aging. Biomedicine \& Pharmacotherapy 57:251-260.

GOLDMAN, IL. 2003. Recognition of fruit and vegetables as healthful: vitamins and phytonutrients. HortTechnology 13(2):252-258.

GRAY, J, ARMSTRONG, G \& FARLEY, H. 2003. Opportunities and constraints in the functional food market. Nutrition \& Food Science 33:213-218.

GRONLUND, NE. 1993. Writing selection items: multiple choice. In Gronlund, NE. How to make achievement tests and assessments. $5^{\text {th }}$ ed. Needham Heights, Boston. Allyn \& Bacon.

HASLER, CM. 1998. Functional foods: their role in disease prevention and health promotion. Food Technology 52:63-70.

HASLER, CM. 2000. The changing face of functional foods. Journal of the American College of Nutrition 19:499S-506S.

HASLER, CM, BLOCH, AS \& THOMSON CA. 2004. Position of the American Dietetic Association: functional foods. Journal of the American Dietetic Association 104:804-826.

INTERNATIONAL FOOD INFORMATION COUNCIL FOUNDATION (IFICF). 2002. Functional foods: attitudinal research. Available online. URL: http://www.ific.org/research/funcfoodsres02.cfm?renderforprint $=1$. Accessed 13 October 2004.

KIRK, SFL, CADE, JE, BARRETT, JH \& CONNER, M. 1999. Diet and lifestyle characteristics associated with dietary supplement use in women. Public Health Nutrition 2:69-73.

KURZER, MS \& XU, X. 1997. Dietary phytoestrogens. Annual Review of Nutrition 17:353-381.

LANGENHOVEN, ML, WOLMARANS, P, JOOSTE, PL, DHANSAY, MA \& BENADÉ, AJS. 1995. Food consumption profile of the South African adult population. South African Journal of Science 91:523-528.

LEVY, AS \& SCHUCKER, RE. 1987. Patterns of nutrient intake among dietary supplement users: attitudinal and behavioural correlates. Journal of the American Medical Association 87:754-760.

LYLE, BJ, MARES-PERLMAN, JA, KLEIN, BEK \& GREGER, JL. 1998. Supplement users differ from nonusers in demographic, lifestyle, dietary and health characteristics. Journal of Nutrition 128:2355-2362.

MCGUIRE, R. 2004. Food industry trends: presentation. Cape Technikon, Cape Town, South Africa. February.

MILLER, LB. 2002. Phytochemicals as a motivational tool to change fruit, vegetables and whole grain consumption. Available online. URL: http://www.uwstout.edu/lib/thesis/2002/2002millerl.pdf. Accessed 10 October 2005.

MOLLET, B \& ROWLAND, I. 2002. Functional foods: at the frontier between food and pharma. Current Opinion in Biotechnology 13:483-485.
NATIONAL INSTITUTE OF NUTRITION. 2000. Consumer awareness of attitudes toward functional foods. Ottawa. National Institute of Nutrition.

NEALL, B. 2005. Soy on the move in SA. Food Technology 59:16-17.

INSTITUTE OF FOOD TECHNOLOGISTS. 2005. Expert report on functional foods: opportunities and challenges. Available online. URL: http://members.ift.org/NR/rdonlyres/48B566FD-6412-4A3D-A0C5E0E2E218BE99/0/BringingtoMarket.pdf. Accessed 11 October 2005.

SIZER, FS \& WHITNEY, EN. 2003. Nutrition: concepts and controversies. $9^{\text {th }}$ ed. Belmont, California. West/ Wadsworth.

SLESINSKI, MJ, SUBAR, AF \& KAHLE, LL. 1996. Dietary intake of fat, fibre and other nutrients is related to the use of vitamin and mineral supplements in the United States: the 1992 National Health Interview Survey. Journal of Nutrition 126:3001-3008.

SLOAN, AE. 1998. Food industry forecast: consumer trends to 2020 and beyond. Food Technology 52:3744.

SLOAN, AE. 2007a. Top 10 food trends. Food Technology 4:22-39.

SLOAN, AE. 2007b. Emerging health and wellness markets: health concerns and product interests of Boomers, Hispanics and children reveal the up-andcoming markets of tomorrow. Nutraceuticals World (September):36-49.

SLOAN TRENDS, INC. 2007. TrendSense ${ }^{T M}$ Available online. URL: http://sloantrend.com/trendsense.aspx. Accessed 26 April 2008.

STABLES, GJ, SUBAR, AF, PATTERSON, BH, DODD, K, HEIMENDINGER, J, VAN DUYN, MS \& NEBELING, L. 2002. Changes in vegetable and fruit consumption and awareness among US adults: results of the 1991 and 19975 A Day for Better Health Program surveys. Journal of the American Dietetic Association 102:809-817.

STEINMETZ, KA \& POTTER, JD. 1996. Vegetables, fruit and cancer prevention: a review. Journal of the American Dietetic Association 96:1027-1039.

THORNDIKE, RM, CUNNINGHAM, GK, THORNDIKE, RL \& HAGEN, EP. 1991. Measurement and evaluation in psychology and education. $5^{\text {th }}$ ed. New York. MacMillan.

WITWER, RS. 1999. Marketing bioactive ingredients in food products. Food Technology 53:50-53.

WORTHINGTON, J \& ZAMMER, C. 2000. Nutraceuticals: developing a strategy. In Food Product Design. Available online. URL: http://www.foodproductdesign.com/archive/2000/0400CS.html. Accessed16 September 2005.

WRICK, KL, FRIEDMAN, LJ, BREWDA, JK \& CARROL, JJ. 1993. Consumer viewpoints on "designer foods". Food Technology 47:94-104. 